UDC 373.035:39(=161.1)-029:93/94 «19»(09)

DOI https://doi.org/10.37915/pa.vi47.167

Binytska K. M. ,

orcid.org/0000-0002-2111-5275

Melnyk R. M. ,

orcid.org/0000-0002-1101-6812

Shabaltina S. M. *,

orcid.org/0000-0001-5160-5147

\title{
ANALYSIS OF THE MODERN SOURCE BASE OF THE PROBLEM OF UKRAINIANIZATION OF SCHOOLS IN THE INTERWAR TWENTY YEARS OF THE 20TH CENTURY
}

The article considers a number of modern publications dedicated to the study of various aspects of the problem of Ukrainianization of schools during the interwar period of twenty years of the 20th century in Ukraine. The preconditions and directly the process of implementation of the policy of Ukrainization in the period of the interwar twenty years of the 20th century in Ukraine have been analyzed.

The objective of the article is to analyze the modern source base on the problem of Ukrainianization of schools in the interwar period of twenty years of the 20th century in Ukraine.

Modern scientific articles, monographs and dissertations dedicated to the study of the problem of Ukrainization during the interwar twenty years of the 20th century have been analyzed. The considered scientific investigations in view of the time of writing have a certain subjective approach, but they give the opportunity to reveal the main directions of Ukrainianization of schools during the interwar twenty years of the 20th century.

It is emphasized that the interest of scientists in the problems of Ukrainianization of school education began in the second half of the 1980-s. During this period, researchers began to study the accumulated archival material, taken from previously banned funds, and finally began a conceptual reassessment of events and processes that took place in the 1920-1930-s.

The study of modern scientific publications dedicated to various aspects of the policy and the process of Ukrainianization of schools during the interwar period of twenty years of the 20th century in Ukraine led to the conclusion that they are conducted in the following areas: analysis of regional processes of Ukrainization, in particular in Volyn region in 1921-1939, the Ukrainization of schools in Slobozhanshchyna and eastern Galicia in the second half of the nineteenth - first half of the twentieth century; the problems of repressions and Ukrainization of the interwar period of twenty years of the 20th century; processes of Ukrainization of secondary school in Ukraine in the 1920-1930-s; processes of Ukrainization of higher technical school in the 1920-1930-s by examples of Kyiv Polytechnic Institute.

Key words: process, Ukrainization, analysis, publications, education, schools, science, Ukraine.

The statement of the issue. Today, in the conditions of strengthening national-patriotic movements and raising the national self-consciousness of modern Ukrainian society, the interest of domestic scholars in studying the Ukrainization of schools during the interwar twenty years of the $20^{\text {th }}$ century in Ukraine is noticeably actualized. The urgency of the topic is also due to the fact that the processes of Ukrainization during the interwar twenty years of the $20^{\text {th }}$ century in Ukraine play a particularly important role today in the period of active transformations, the formation of civil society and the creation of national self-identity. Therefore, the experience of Ukrainization in the interwar twenty years of the $20^{\text {th }}$ century

\footnotetext{
*C Binytska K. M.

*C Melnyk R. M.

*C) Shabaltina S. M.
}

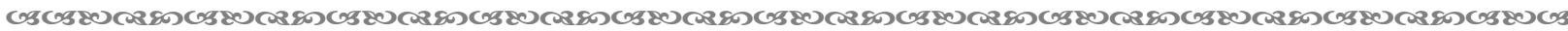


makes it possible to more fully comprehend the essence and significance of Ukrainian language for the modern Ukrainian state.

The analysis of relevant research. Problems of development of Ukrainian schooling in the 1920-s - early 1930-s were studied by Nikolina I. Regional processes of Ukrainization policy, in particular in Volyn, Slobozhanshchyna and eastern Galicia in the second half of the $19^{\text {th }}$ - first half of the $20^{\text {th }}$ century were investigated by Ukrainian scientists Kramar Yu., Mankivska T., Tserkovnyk S. Zhorova I. and Sushko V., who studied the tendencies of Ukrainization in educational institutions of Ukraine in the 1930-s. Loza H. on the example of Kyiv Polytechnic Institute activities highlighted the process of Ukrainization of higher technical school in the 1920-1930-s.

The purpose of the article. The objective of the article is to analyse the modern source base on the problem of Ukrainianization of schools in the interwar twenty years of the $20^{\text {th }}$ century in Ukraine.

The body of the research. Modern tendencies in the development of domestic pedagogical science have led to growing interest in studying the processes of Ukrainization during the interwar twenty years of the $20^{\text {th }}$ century in Ukraine; in particular, the experience of Ukrainianization of schools is quite interesting. Careful study of the main forms of Ukrainization in historical retrospect, systematization and analysis of everything that was written about it in previous years remains relevant today, as these factors largely determine the socio-economic and cultural state of the society, ethno-national course, demographic policy of our state and the national self-identity of Ukrainian society [15, p. 10].

Historic-pedagogical researches on the issues of Ukrainization are relevant for modern scientific researches due to the large number of modern scientific studies [1, p. 58]. Therefore, we believe that the analysis of the modern source base of the problem of Ukrainianization of schools during the interwar twenty years of the $20^{\text {th }}$ century in Ukraine is relevant, given the fact that certain provisions of the law "On Ensuring the Functioning of the Ukrainian Language as the State Language" enter into force on January 16, 2021 [3].

Let's analyze in more details the prerequisites for the implementation of the policy of Ukrainization in the interwar twenty years of the $20^{\text {th }}$ century. The aggressive policy of Russification of the Russian Empire over the centuries has led to the Ukrainian language being completely pushed out of official use. The language of all government agencies, courts, schools, universities, scientific and artistic institutions was Russian. In fact, the Ukrainian language was the language of the Ukrainian countryside. The cities were totally russified. For example, on September 16, 1917, the Kyiv City Statistical Bureau conducted a census of "all Kyivans" to determine the social composition of the urban population. It turned out that 467,591 people live in Kyiv (258,505 of them are women). This ratio was caused by the war many men went to the front. Ukrainians were $-12 \%$, Little Russians $-4.4 \%$, Russians $-49.5 \%$, Poles $-9.2 \%$, Jews $-18.7 \%$, other nationalities $-4.7 \%$, persons who have not defined nationality $-1.5 \%$. In the Ukrainian city there were only one-sixth of Ukrainians. Another census of Kyivans was conducted on March 18, 1919. According to this census, the total population was 544,369 people. Of them: Ukrainians were $-23.6 \%$, Little Russians $-1.5 \%$, Russians $-42.6 \%$, Poles $-6.8 \%$, other nationalities $-3.7 \%$, undecided nationality $-0.7 \%$. The result: only every fourth Kyiv resident registered himself or herself as a Ukrainian [10].

At the beginning of the twentieth century, the highest aristocratic circles dared to speak, or rather had the courage and dignity to use Ukrainian, a very small number of people, in particular, the Kosach-Drahomanov family, the Lysenkos, that is, representatives of the old community. The Ukrainian language got a huge chance during the times of the Ukrainian People's Republic and the Hetmanate. Then the Ukrainian press was restored, book printing in the Ukrainian language was revived, the Ukrainian theater appeared, Ukrainian schools began to open, and the Ukrainian Academy of Sciences was founded. At this time, our state received a vital "vaccination in the Ukrainian language", which allowed to preserve the Ukrainian language and national identity until the independence in 1991 [13].

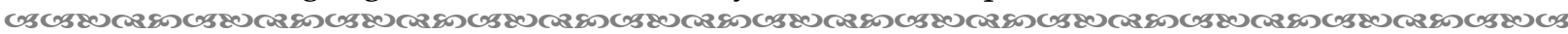
190 
Ukrainization was mandatory for all civil servants and contained some element of coercion. They had to pass exams in the Ukrainian language and culture. For those who did not speak the language, courses were opened that were initially free. Classes began after work, two additional hours after working day. Of course, many people did not like it and Ukrainization caused outrage. From 1927, those who lagged behind in Ukrainization had to pay for tuition. Civil servants who could not pass the exam, or avoided training in any way, were fired without the right to receive unemployment benefits. Those who passed the exam had to use the Ukrainian language in writing and orally, when communicating with visitors and various organizations. Instructor courses at the institutions were subject to the Central State Courses of Ukrainian Studies in Kharkiv, which drafted programs and trained instructors who monitored the course of Ukrainization in various institutions and organizations. For example, the Ukrainian language instructor at the courses for Ukrainian secret service agents (Cheka) was the writer Z. Tulub [12].

The processes of Ukrainization began to collapse in the 1930-s, for example, in 1930 the Ukrainian language courses were closed. In 1933, the new Ukrainian spelling was introduced, which was significantly closer to the Russian language. Since then, Soviet scholars have had to keep a close eye on the Ukrainian language, guiding it in the right direction. The Ukrainian language was not banned, but was taken under full state control [12].

Scholars' interest in the problems of Ukrainization began in the second half of the 1980-s. They started to study the accumulated archival material, taken from previously banned funds, and finally began a conceptual reassessment of the events that took place in the 1920-s and the processes, as well as the activities of political leaders of that time. Researchers who worked in the 1980-s were most interested in the following aspects of Ukrainization: the reasons for adopting this policy, its true content and results, the reasons for its collapse and the importance of this policy in the context of modern tasks of national revival [7, p. 33].

Let us analyze some works of modern domestic scholars who have fully or indirectly considered the processes of Ukrainization. The considered works in view of the time of writing have a certain subjective approach, but still they give the chance to reveal the basic directions of Ukrainization of schools the period of interwar twenty years of the $20^{\text {th }}$ century.

Thus, in the monographic study of I. Nikolina "Secondary School of Ukraine in the 1920-s - early 1930-s" the influence of Ukrainization on schools for the representatives of Ukrainian and other nationalities of Ukraine is revealed. The author studied the theses of the Politburo of the Central Committee of the Communist Party (Bolsheviks), in which Ukrainization was interpreted as "a necessary means of socialist construction, as an instrument of socialist construction in the hands of the Ukrainian working masses" [8, p. 76].

The concept of Ukrainization required the spread of communist slogans among the peasant masses, making them understandable when translated into Ukrainian [9, p. 35]. I. Nikolina emphasizes that although officially Ukrainization started in 1923, the main campaign for its introduction into the school system began only in 1925 [9, p. 38].

The dissertation research of Tserkovnyk S. "Formation and Functioning of Ukrainian Scientific, Public and Cultural-Educational Institutions of Eastern Galicia in the Second Half of the $19^{\text {th }}$ - first half of the $20^{\text {th }}$ Century: Historical and Legal Dimension" highlights that 1848 created some opportunities for Ukrainianization of secondary schools and awakening of political consciousness of the people. At the request of the Main Russian Council, a compulsory subject, the Ukrainian language, was introduced in secondary schools in Eastern Galicia. Polish was transferred to the category of free subjects, and it was decided to keep German until qualified Ukrainian teachers come to school [14, p.107].

In Yu. Kramar's dissertation research "National-Cultural and Religious Policy of the Polish Governments in Volyn (1921-1939)" the problem of Ukrainization of the Orthodox Church in Volyn in 1921-1939 was studied. The author concludes that in 1925 the preservation of Russian nature of Orthodoxy provoked opposition from the population in Volyn region. 
This dissatisfaction manifested itself in the movement for the Ukrainization of the Orthodox Church. Therefore, in order to prevent the region from getting out of the control of the authorities, the Polish authorities agreed to the Ukrainization of the Orthodox Church (in particular, the Ukrainian pronunciation was introduced in liturgies, sermons were also in Ukrainian) [5, c. 22]. Already in the mid-1930-s, the process of Ukrainization of the Orthodox Church in Volyn region was a great success [5, p. 34].

In our opinion, the work of T. Mankivska is quite interesting for studying the topic. The researcher studied the problem of Ukrainianization of schools in Slobozhanshchyna during the national liberation struggle (1917-1918). In her scientific research, the author notes that the Ukrainization of schools in Slobozhanshchyna was accompanied by a number of problematic issues:

- the previous policy of the government of the Russian Empire and the holding of a number of old tsarist officials;

- lack of textbooks in Ukrainian;

- lack of procedures and practices of public opinion polls;

- insufficiency of short summer courses for thorough training of teachers;

- the impact of teacher training conducted in the pre-revolutionary period [6, p. 42].

$\mathrm{Yu}$. Kovaliv when studying the problem of repressions of the interwar twenty years of the $20^{\text {th }}$ century notes that discriminatory measures were intensified by Bolshevik Moscow, which was forced to temporarily give in to a wave of nationally conscious movements in the union republics called "indigenization". In Ukraine in particular, this process is known as Ukrainization. Ukrainization was supported and implemented by the National Communists. As a result of these processes, Ukrainization took place through the expansion of national education and in $80 \%$ of primary and secondary schools teaching was introduced in the Ukrainian language. $89 \%$ of the press was in Ukrainian [4].

I. Zhorova and V. Sushko chose the processes of Ukrainization of secondary school in Ukraine in the 1930-s as the subject of their scientific research. But in the course of the scientific research they conclude that Ukrainization as a socio-political phenomenon under certain historical conditions naturally and logically arose in connection with the official introduction of the Ukrainian language in all spheres of public life in Soviet Ukraine in the early 1920-s with the introduction of the official policy of "indigenization", the declared political-economic course on cultural construction in the country, just as naturally and logically in those days ideological political system in the USSR has come to its end [2, p. 254].

Thus, one of the undisputed achievements of the policy of Ukrainization was the Ukrainization of primary schools. If in 1922 there were 6105 Ukrainian schools, in 1930 14430 (Russian - 1504). At the end of 1927, $77 \%$ of Ukrainians attended these schools. The situation with the Ukrainization of universities was a little worse, in 1929 the institutes were ukrainianized only by $30 \%$ [11].

In the context of the above mentioned, it is advisable to consider the scientific research of H. Loza. The author studies the process of Ukrainization of the higher technical school of the 1920-s and 1930-s on the example of activity of Kyiv Polytechnic Institute. Thus, the most active period of Ukrainization for science and public administration of Soviet Ukraine was the period of 1921-1930. At the VII Conference of the Communist Party (Bolsheviks) of Ukraine on April 4-10, 1923, the decision was made to ukrainize state institutions. In the 1929/1930 academic year, all higher education institutions considered to be ukrainianized by $40 \%$, the lecturers by $39.5 \%$ were Ukrainian, the number of Ukrainians among students increased to $62.8 \%$, in the 1930/1931 academic year - to more than $70 \%$ [11].

Ukrainization of the1920-s - early 1930-s contributed to the expansion of the spheres of functioning of the Ukrainian language, in particular in higher education institutions. Thus, increasing the prestige of the Ukrainian language among the scientific and pedagogical staff of Kyiv Polytechnic Institute gave the opportunity, despite its gradual collapse, to create real conditions for the training of patriotic graduates and lay the foundation for further

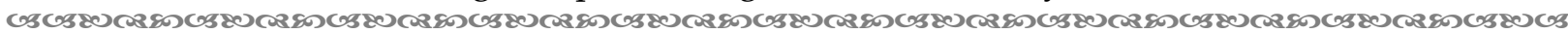
192 
development of Ukrainian scientific and educational books. However, over the time, the lack of real state sovereignty of the Ukrainian SSR, inconsistency and half-heartedness of the government's national policy, increasing ideological pressure on teachers significantly limited the opportunities for scientific work and reduced the social status of the scientific intelligentsia, which ultimately led to the complete collapse of the construction of the Ukrainian model of education. For a long time, Kyiv Polytechnic Institute stopped teaching in the native language and publishing scientific and educational literature, which negatively affected the development of technical Ukrainian-language and other professional literature [11].

Conclusions. In the process of research, modern scientific publications were developed, which are related to various aspects of Ukrainianization of schools during the interwar twenty years of the $20^{\text {th }}$ century in Ukraine. As part of the research, we used modern scientific publications, monographs and dissertations on the mentioned issue.

Study of modern scientific publications dedicated to various aspects of the problem of Ukrainianization of schools during the interwar twenty years of the $20^{\text {th }}$ century allowed to determine the following areas of scientific researches:

- dissertation researches analyze regional processes of Ukrainization, in particular on the example of Volyn region in 1921-1939, Ukrainization of schools in Slobozhanshchyna and eastern Galicia in the second half of the $19^{\text {th }}$ - the first half of the $20^{\text {th }}$ century; century;

- problems of repressions and Ukrainization of the interwar twenty years of the $20^{\text {th }}$

- processes of Ukrainization of secondary school in Ukraine in the 1920-s and 1930-s;

- processes of Ukrainization of the higher technical school of the 1920-1930-s on the example of Kyiv Polytechnic Institute.

The above mentioned allowed us to conclude that at the present stage of development of the history of pedagogics some scientific literature related to the study of various aspects of the problem of Ukrainization has been accumulated. Today there is a public demand, and in the Ukrainian pedagogical space it is time to write works that would cover all aspects of the problem of Ukrainianization of schools. However, the comprehensive historical-pedagogical analysis of the problem of Ukrainianization of schools in the interwar twenty years of the $20^{\text {th }}$ century, which is the basis for further researches, has not yet been carried out.

\section{Bibliography:}

1. Біницька К. М. Педагогічна історіографія - сучасний стан напряму історико-педагогічних досліджень. Педагогічний дискурс. 2013. Вип. 15. С. 58-62.

2. Жорова І., Сушко В. Українізація загальноосвітньої школи в Україні в 1930-х роках. Педагогічні науки: теорія, історія, інноваційні технології: науковий журнал / [редкол.: А. А. Сбруєва, О. А. Біда, Ю. А. Бондаренко та ін.]. Суми : СумдПУ ім. А. С. Макаренка, 2019. № 10 (94). C. $248-257$.

3. Закон України «Про забезпечення функціонування української мови як державної». URL: https://zakon.rada.gov.ua/laws/show/2704-19

4. Ковалів Ю. Дантові кола репресій України міжвоєнного двадцятиліття. Слово Просвіти. URL: http://slovoprosvity.org/2017/11/23/dantovi-kola-represij-ukrajiny-mizhvojennohodvadtsyatylittya-3/

5. Крамар Ю. В. Національно-культурна та релігійна політика урядів Польщі на Волині (19211939 рр.): дис. ... А-ра істор. наук / Львівський національний університет імені Івана Франка, Аьвів, 2015. 536 с.

6. Маньківська Т. О. Українізація шкіл і вчительство на Слобожанщині у 1917-1918 роках. Наука. Рехіzія. Суспільство. 2012. № 4. С. 41-45.

7. Марискевич Т. Історіографія поняття «українізація». Наукові Виклади. 2010. № 5. С. 33-35.

8. Національні процеси в Україні: історія і сучасність. Документи і матеріали: Довідник. У 2 ч. Ч. 2. Упоряд. І. О. Кресіна, В. Ф. Панібудьласка. Київ: Вища школа, 1997. 704 с. 
9. Ніколіна I. I. Загальноосвітня школа України 20-х - початку 30-х рр. XX ст. Вінниця, 2013. 208 c.

10. Переписи населения. Киев. URL: https://zn.ua/HISTORY/perepisi-naseleniya-kiev-331737 .html

11. Українізація вищої технічної школи 20-30-х pp. XX ст. на прикладі KПI. URL: https://kpi.ua/ukrainianization

12. Українізація по-московськи: пряник, що став батогом, або як більшовики українців українізували. URL: https://www.ukrinform.ua/rubric-polytics/2575613-ukrainizaciapomoskovski-pranik-so-stav-batogom-abo-ak-bilsoviki-ukrainciv-ukrainizuvali.html

13. Церковник С. I. Становиення та функціонування українських наукових, громадських та культурно-освітніх інституцій Східної Галичини в другій половині XIX - першій половині XX століття: історико-правовий вимір: дис. ... канд. юр. наук / Львівський державний університет внутрішніх справ. 2018. 211 с.

14. Binytska K. M., Nahornyi Ya. V., Binytska O. P. Educational and cultural activity of the society «Prosvita» on the territory of Volyn (in the period of the interwar twenty years of the XX century) Педагогіка формування творчої особистості у вищій і загальноосвітній школах. 2020. № 68, т. 1. C. 10-14.

\section{References:}

1. Binytska, K. M. (2013). Pedahohichna istoriohrafiia - suchasnyi stan napriamu istorykopedahohichnykh doslidzhen [Pedagogical historiography - the current state of historical and pedagogical research]. Pedahohichnyi dyskurs, 15, 58-62 [in Ukrainian].

2. Zhorova, I., \& Sushko, V. (2019). Ukrainizatsiia zahalnoosvitnoi shkoly v Ukraini v 1930-kh rokakh [The state of the process of Ukrainianization of a general education school in Ukraine in the 1930s]. Pedahohichni nauky: teoriia, istoriia, innovatsiini tekhnolohii, 10 (94), 248-257 [in Ukrainian].

3. Law of Ukraine On ensuring the functioning of the Ukrainian language as the state language. Retrieved from https://zakon.rada.gov.ua/laws/show/2704-19 [in Ukrainian].

4. Kovaliv, Yu. (2020). Dantovi kola represii Ukrainy mizhvoiennoho dvadtsiatylittia [Dante's circles of repression in Ukraine in the interwar twentieth century]. Slovo Prosvity. Retrieved from http://slovoprosvity.org/2017/11/23/dantovi-kola-represij-ukrajiny-mizhvojennohodvadtsyatylittya-3/ [in Ukrainian].

5. Kramar, Yu. V. (2015). Natsionalno-kulturna ta relihiina polityka uriadiv Polshchi na Volyni (19211939 rr.) [National-cultural and religious policy of the Polish governments in Volyn (1921-1939)]. (Doctor's thesis). Ivan Franko National University of Lviv. Lviv [in Ukrainian].

6. Mankivska, T. O. (2012). Ukrainizatsiia shkil i vchytelstvo na Slobozhanshchyni u 1917 - 1918 rokakh [Ukrainization of schools and teaching in Slobozhanshchyna in 1917 - 1918]. Nauka. Relihiia. Suspilstvo, 4, 41-45 [in Ukrainian].

7. Maryskevych, T. (2010). Istoriohrafiia poniattia "ukrainizatsiia" [Historiography of the concept of "Ukrainization"]. Naukovi Vyklady, 5, 33-35 [in Ukrainian].

8. Kresina, I. O. \& Panibudlaska, V. F. (1997). Natsionalni protsesy v Ukraini: istoriia $i$ suchasnist. Dokumenty $i$ materialy [National processes in Ukraine: history and modernity. Documents and materials]. (Vol. 2). Kyiv: Vyshcha shkola [in Ukrainian].

9. Nikolina, I. I. (2013). Zahalnoosvitnia shkola Ukrainy 20-kh - pochatku 30-kh rr. XX st. [Secondary school of Ukraine in the 20's - early 30's of the twentieth century]. Vinnytsia [in Ukrainian].

10. Perepisi naseleniia [Population census]. Retrieved from https://zn.ua/HISTORY/perepisinaseleniya-kiev-331737 .html [in Russian].

11. Ukrainizatsiia vyshchoi tekhnichnoi shkoly $20-30-k h$ rr. XX st. na prykladi KPI [Ukrainization of the higher technical school of the 20s and 30s of the XX century on the example of KPI]. Retrieved from https://kpi.ua/ukrainianization [in Ukrainian].

12. Ukrainizatsiia po-moskovsky: prianyk, shcho stav batohom, abo yak bilshovyky ukraintsiv ukrainizuvaly [Ukrainization as in Moscow: gingerbread, which became a whip, or as the Bolsheviks Ukrainianized Ukrainians]. Retrieved from https://www.ukrinform.ua/rubricpolytics/2575613-ukrainizacia-pomoskovski-pranik-so-stav-batogom-abo-ak-bilsoviki-ukraincivukrainizuvali.html [in Ukrainian].

13. Tserkovnyk, S. I. (2018). Stanovlennia ta funktsionuvannia ukrainskykh naukovykh, hromadskykh ta kulturno-osvitnikh instytutsii Skhidnoi Halychyny v druhii polovyni XIX - pershii polovyni XX stolittia: istoryko-pravovyi vymir [The formation and functioning of Ukrainian scientific, public and culturaleducational institutions of Eastern Halychyna in the second half of the XIX - the first half of the XX 
century: the historical and legal dimension]. (Candidate's thesis). Lviv State University of Internal Affairs of the Ministry of Internal Affairs of Ukraine. Lviv [in Ukrainian].

14. Binytska, K. M., Nahornyi, Ya. V., \& Binytska, O. P. (2020). Educational and cultural activity of the society "Prosvita" on the territory of Volyn (in the period of the interwar twenty years of the XX century). Pedahohika formuvannia tvorchoi osobystosti u vyshchii i zahalnoosvitnii shkolakh, 68, 1, 10-14 [in English].

Біницька К. М., orcid.org/0000-0002-2111-5275

Мельник Р. М., orcid.org/0000-0002-1101-6812,

Шабалтіна С. М.,

АНАЯІЗ СУЧАСНОЇ ДЖЕРЕЯЬНОЇ БАЗИ ПРОБЛЕМИ УКРАЇНІЗАЦІЇ ШКІ orcid.org/0000-0001-5160-5147 У ПЕРІОД МІЖВОЕННОГО ДВАДЦЯТИЯІТТЯ ХХ СТ.

У статті розглянуто низку сучасних публікацій, присвячених вивченню різних аспектів проблеми українізації шкіл у періодміжвоєнного двадияттиліття ХX ст. в україні. Проаналізовано передумови та безпосередньо процес упровадження політики українізації в період міжвоєнного двадиятиліттяя ХХ ст. в Украӥні.

Метою статті є аналіз сучасної джерельної бази щцоо проблеми українізації шкіл у період міжвоєнного двадиялтиліття ХХ ст. в Украйні.

Проаналізовано сучасні наукові статті, монографії і дисертаційні роботи, які присвячені вивченню проблеми українізації у період міжвоєнного двадиятииліття ХХ сm. Розглянуті наукові розвідки з огляду на час написання мають певний суб'єктивний підхід, але дають можливість розкрити основні напрями українізації шкіл у період міжвоєнного двадиялтиліття $X X \mathrm{~cm}$.

Акцентовано, щъо зацікавленість науковців проблемами українізацій щкільної освіти почалася з другої половини 80-х років ХХ ст. У цุей період дослідники почали опрацьвовувати накопичений архівний матеріал, узятий із заборонених раніше фондів, нарешті, почалася концептуальна переоцінка подій і процесів, які відбувалися в 1920-1930-ті роки.

Вивчення сучасних наукових публікацій, які присвячені різним аспектам політики та процеесу українізациї шкіл у період міжвоєнного двадиялтиліття ХХ ст. в Украйні, дозволило дійти висновку, що вони проводяться за такими напрямами: аналіз регіональних процесів українізациї, зокрема на Волині у 1921-1939 рр., украйнізациї шкіл Слобожанщцини та Східної Галичини в другій половині XIX - першій половині XX століття; проблеми репресій та

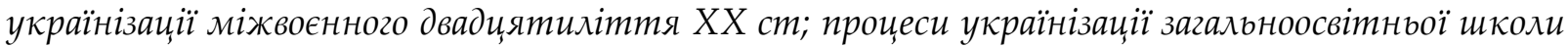
в Україні у 1920-1930-х рр.; процеси українізаціӥ вищої технічної школи у 20-30-х рр. ХХ ст. на прикладі КПI.

Ключові слова: процес, украӥнізація, аналіз, публікації, освіта, щколи, наука, Украйна.

Дата надходження статmі: 22.122020 p. Рецензент: доктор педагогічних наук, професор Галус О. М. 